\title{
IMPLEMENTASI HAK WARGA NEGARA MELALUI PENANGGULANGAN KEMISKINAN BERPERSPEKTIF GENDER PROGRAM KELUARGA HARAPAN TERHADAP MOTIVASI BELAJAR ANAK KELUARGA PENERIMA MANFAAT DI KABUPATEN SINTANG
}

\author{
Suparno, Juri, Dessy Triana Relita \\ Program Studi Pendidikan Pancasila dan Kewarganegaraan, STKIP Persada Khatulistiwa Sintang \\ Jl. Pertamina Km 4 Sengkuang Sintang Kalimantan Barat \\ Email: suparnowae4@gmail.com
}

\begin{abstract}
The purpose research was to find out how the implementation citizens' rights through poverty alleviation with a gender perspective is a family program hope towards the learning motivation children beneficiary families in Sintang district. This research is motivated by the conditions poverty in Indonesia is quite high. Based on the research found that in Sintang: 1). The implementation of Citizens' Rights through Poverty Reduction with Gender Perspective The Family Hope Program has been implemented well; 2). Learning Motivation for Children Beneficiary Families is very good, it can be seen from the number KPM children who excel in both academic and non-academic fields. There are 59 children who excel both locally, nationally and internationally; 3 ). The Implementation Citizens' Rights through Poverty Alleviation with Gender Perspective Family Hope Program Against Learning Motivation Beneficiary family children are very relevant, because it has been able to facilitate underprivileged children to gain access to education as citizens' rights, such as access to facilities in obtaining scholarships and relief tuition fees with assistance received in cash.
\end{abstract}

Keywords: citizen rights, gender perspective, hope family program,learning

\begin{abstract}
Abstrak: Tulisan ini bertujuan untuk mengetahui bagaimana Implementasi Hak Warga Negara Melalui Penanggulangan Kemiskinan Berspektif Gender Program Keluarga Harapan Terhadap Motivasi Belajar Anak Keluarga Penerima Manfaat di Kabupaten Sintang.Kajian ini dilatarbelakangi oleh kondisi Kemiskinan di Indonesia yang cukup tinggi. Berdasarkan hasil kajian ditemukan bahwa di Kabupaten Sintang: 1). Implementasi Hak Warga Negara Melalui Penanggulangan Kemiskinan BerspektifGender Program Keluarga Harapan sudah terlaksana dengan baik; 2). Motivasi Belajar Anak Keluarga Penerima Manfaat sangat baik, hal tersebut dapat dilihat dari banyaknya anak-anak KPM yang berprestasi baik dibidang akademik maupun non akademik. Terdapat 59 anak yang berprestasi baik ditingkat lokal, naisonal maupun internasional; 3). Implementasi Hak Warga Negara Melalui Penanggulangan Kemiskinan Berspektif Gender Program Keluarga Harapan Terhadap Motivasi Belajar Anak Keluarga Penerima Manfaat sangat relevan, karena telah mampu memfasilitasi anak yang kurang mampu untuk memperoleh akses pendidikan sebagai hak warga negara, seperti akses kemudahan dalam memperoleh beasiswa dan keringanan biaya pendidikan dengan bantuan yang diterima secara tunai.
\end{abstract}

Kata Kunci: hak warga Negara, berperspektif gender, program keluarga harapan, motivasi belajar

Kemiskinan merupakan masalah utama yang dialami oleh hampir semua negara-negara berkembang di dunia. kemiskinan Di Indonesia merupakan masalah yang kompleks yang memerlukan penanganan dan program yang khusus dari masa ke masa. Masalah kemiskinan bukan lagi sekedar masalah negara, akan tetapi menjadi masalah sosial yang menyangkut hampir semua aspek dalam interaksi sosial. Masalah kemiskinan menjadi salah satu faktor penyebab 
dari kompleksitas permasalahan negara. UNESCO telah meluncurkan Sustainable Depelopment Goal Education 2030.

Angka kemiskinan di Indonesia mengalami kenaikan dari tahun ke tahun. Badan Pusat Statistik (BPS) menginformasikan, jumlah penduduk miskin (penduduk dengan pengeluaran per kapita per bulan di bawah Garis Kemiskinan) di Indonesia per September 2016 mencapai 27,76 juta orang (10,70 persen) (http://setkab.go.id/bps-perseptember-2016-jumlah-penduduk-miskinindonesia-bekurang-025-juta/). Data ini membuktikan bahwa tingkat kemiskinan di Indonesia tinggi, dengan demikian perlu adanya upaya penanganan yang serius terutama bagi pemerintah yang memiliki tugas dan wewenang untuk mensejahterakan rakyat. Menyikapi masalah ini pemerintah mulai mengupayakan berbagai cara penanggulangan melalui berbagai pendekatan yang relevan. Ada tujuh belas target yang menjadi pekerjaan rumah Indonesia diantaranya adalah "menurunkan angka kemiskinan, menurunkan angka kelaparan, meningkatkan kesehatan dan kesejahetaraan"

Pemerintah selaku pemegang kekuasaan tertinggi berkewajiban melaksanakan berbagai program dan stimulus untuk mengatasi masalah kemiskinan. Sebagaimana yang diamanahkan pada pasal 34 ayat 2 UUD 1945 menyatakan bahwa "negara mengembangkan sistem jaminan sosial bagi seluruh rakyat dan memberdayakan masyarakat yang lemah dan tidak mampu sesuai dengan martabat kemanusiaan". Salah satu program khusus yang dikeluarkan pemerintah dalam rangka percepatan penanggulangan kemiskinan adalah Program Bantuan Tunai Bersyarat yang dikenal dengan nama Program Kelurga Harapan (PKH) yang dilaksanakan sejak tahun 2007. PKH sebagai upaya membangun sistem perlindungan sosial kepada masyarakat miskin dalam rangka mempertahankan dan meningkatkan kesejahteraan sosial penduduk miskin sekaligus sebagai upaya memotong rantai kemiskinan yang berbasis gender.

Target sasaran penerima adalah rumah tangga/keluarga sangat miskin (RTSM/KSM) atau kelompok masyarakat berada pada kluster 1 (satu) yang dilihat dari perspektif ibu-ibu/gender. Mulai tahun 2012, calon perserta PKH adalah rumah tangga/keluarga dengan peringkat kesejahteraan tujuh persen $(7 \%)$ terendah. (Kajian program keluarga harapan direktorat jenderal anggaran kementerian keuangan, 2015).PKH bertujuan untuk memberikan transfer sosial bagi orang miskin dan untuk mengurangi kemiskinan dan ketimpangan dengan memberikan insentif pada keluarga miskin untuk berinvestasi dalam modal sumber daya manusia anak-anak mereka. Melalui program PKH yang mencakup tiga bidang kesejahteraan ekonomi, kesehatan dan pendidikan. PKH sebagai program pengentasan kemiskinan berbasis gender ini sangat penting menjadi perhatian, hal ini terlihat dari kedudukannya sebagai: program prioritas nasional dan Center of Excellence penanggulangan kemiskinan yang mensinergikan berbagai program perlindungan dan pemberdayaan sosial nasional.

Program Keluarga harapan di provinsi Kalimantan Barat, khususnya di Kabupaten Sintang sebagai daerah yang termasuk daerah Tertinggal, Terdepan, Terluar (3T), patut mendapatkan perhatian bersama khususnya terkait dengan 3 hal yang bersinergi pada program PKH yakni kesejahteraan, kesehatan dan pendidikan. Menurut data yang diperoleh dari Dinas Sosial dan Tenaga Kerja, tahun 2017 terdapat 9. 430 keluarga penerima manfaat yang tersebar di 14 Kecamatan yang ada di Kabupaten Sintang. Banyaknya keluarga penerima bantuan tersebut, dan telah berjalannya program PKH selama 5 tahun di Kabupaten Sintang, menarik untuk diadakannya pengkajian yang ilmiah oleh para akademisi apakah ada dampak positif sesuai dengan ruh atau semangat sesuai pencapaian visi misi yang menjadi paradigma PKH itu sendiri, terkhusus aspek pendidikan anak Keluarga Penerima Manfaat (KPM).

Setiap warga negara memiliki hak memperoleh pelayanan penuh oleh pemerintah, ketentuan tersebut tentang haknya sebagai warga negara. Hak ini merupakan sesuatu yang melekat pada setiap warga sejak seseeorang tersebut berada didalam suatu negara. Berkaitaan dengan hak warga negara, sebagaimana telah diatur dalam Undang-Undang yang tercantum dibawah ini:

1. Hak atas pekerjaan dan penghidupan yang layak. Pasal 27 ayat (2) UUD 1945 yang berbunyi "tiap-tiap warga negara berhak atas pekerjaan dan penghidupan yang layak bagi kemanusiaan”. Pasal ini menunjukan asa sosial dan keadilan.

2. Hak untuk mendapatkan pengajaran. Pasal 30 ayat (1) UUD 1945 yang berbunyi: ayat (1) tiap-tiap warga negara berhak mendapatkan pengajaran. Adapun dalam ayat (2) dijelaskan 
bahwa pemerintah mengusahakan dan menyelenggarakan satu sistem pengajaran nasional yang diatur dengan UUD 1945.

3. Hak ekonomi atau hak untuk mendapatkan kesejahteraan sosial. Pasal 33 ayat (1), (2), (3), (4), dan (5) UUD 1945 berbunyi:

(1) Perekonomian disusun sebagai usaha bersama berdasar asas kekeluargaan.

(2) Cabang-cabang produksi yang penting bagi negara dan yang menguasai hajat hidup orang banyak dikuasai oleh negara.

(3) Bumi, air dan kekayaan alam yang terkandung didalamnya dikuasai oleh negara dan dipergunakan untuk sebesarbesarnya bagi kemakmuran rakyat.

(4) Perekonomian nasional diselenggarakan berdasar atas demokrasi ekonomi dengan prinsip kebersamaan, efisiensi berkeadilan, berkelanjutan, berwawasan lingkungan, kemandirian, serta dengan menjaga keseimbangan kemajuan dan kesatuan ekonomi nasional.

(5) Ketentuan lebih lanjut mengenai pelaksanaan pasal ini diatur dalam undangundang.

4. Hak mendapatkan jaminan keadilan sosial. Dalam pasal 34 UUD 1945 dijelaskan bahwa fakir miskin dan anak-anak telantar dipelihara oleh negara (Winarno, hal: 58-59).

Kemiskinan merupakan suatu masalah yang berpengaruh terhadaap kemajuan suatu negara, sehingga setiap negara melakukan upaya dalam penanganan dalam menanggulangi kemiskinan. Begitu juga Indonesia masih dilanda adaaya kemiskinan, sehinggaa pemerintah berupaya melakukan trobosan-trobosan dalam menanggulanginya. Dalam menanggulaangi kemiskinan pemerintah mengambil suatu kebijakan yang melibatkan mulai dari pemerintah pusat hingga daerah. Sebagaimana kebijakan tersebut terkandung didalam peraturan Presiden Republik Indonesia No 15 Tahun 2010 Pasal 1 tentang percepaatan penanggulangan kemiskinaan, yaitu:

1. Penanggulangan Kemiskinan adalah kebijakan dan program pemerintah dan pemerintah daerah yang dilakukan secara sistematis, terencana, dan bersinergi dengan dunia usaha dan masyarakat untuk mengurangi jumlah penduduk miskin dalam rangka meningkatkan derajat kesejahteraan rakyat.

2. Program penanggulangan kemiskinan adalah kegiatan yang dilakukan oleh pemerintah, pemerintah daerah, dunia usaha, serta masyarakat untuk meningkatkan kesejahteraan masyarakat miskin melalui bantuan sosial, pemberdayaan masyarakat, pemberdayaan usaha ekonomi mikro dan kecil, serta program lain dalam rangka meningkatkan kegiatan ekonomi.

3. Tim Nasional Percepatan Penanggulangan Kemiskinan merupakan tim lintas sektor dan lintas pemangku kepentingan di tingkat pusat untuk melakukan percepatan penanggulangan kemiskinan.

4. Tim Koordinasi Penanggulangan Kemiskinan Provinsi adalah wadah koordinasi lintas sektor dan lintas pemangku kepentingan untuk penanggulangan kemiskinan di tingkat provinsi.

5. Tim Koordinasi Penanggulangan Kemiskinan Kabupaten/Kota adalah wadah koordinasi lintas sektor dan lintas pemangku kepentingan untuk penanggulangan kemiskinan di tingkat kabupaten/kota.

Berdasarkan penjabaaran Perpres tersebut jelaslah bahwa pemerintah bersama-sama dengan semua elemen yang terkait turut serta dalam penanganan kemiskinan. Hal ini merupakan sebagai strategi yang tepat untuk mengatasinya. Untuk melaksaanakan amanat Perpres yang dimaksud perlu adanya strategi atau langkah riil dalam penanganannya. hal ini seperti yang tertuang dalam Undang-Undang Nomor 40 Tahun 2004 tentang Sistem Jaminan Sosial Nasional, dan di tindaklanjuti melalui Inpres Nomor 3 Tahun 2010 tentang Rencana Tindak Percepatan Pencapaian Sasaran Program Pro Rakyat Yang Berbasis Keluarga. Seperti program pendidikanperlindungan sosial adalah untuk memelihara jasa pelayanan kepada keluarga miskin dengan pembebasan terhadap pembayaran uang sekolah (Soemitro, 2002:31 dalam Purwanto dkk, 2013: 81)

Upaya penanggulangan kemiskinan di Indonesia salah satunya melalui Dinas Sosial berupa suatu program bantuan kepada masyarakat. Adapun program tersebut berupa Program Keluaargaa Harapan (PKH).

PKH ialah program yang memberikan bantuan tunai kepada Rumah Tangga Sangat Miskin (RTSM) jika mereka memenuhi persyaratan yang terkait dengan upaya peningkatan kualitas sumber daya manusia (SDM) yaitu pendidikan dan kesehatan (Tim Direktorat Jaminan Sosial, 2013 :13). Selain itu PKH 
merupakan program lintas Kementerian dan Lembaga, karena aktor utamanya adalah dari Badan Perencanaan Pembangunan Nasional, Departemen Sosial, Departemen Kesehatan, Departemen, Pendidikan Nasional, Departemen Agama, Departemen Komunikasi dan Informatika, dan Badan Pusat Statistik.Untuk mensukseskan program tersebut, maka dibantu oleh Tim Tenaga ahli PKH dan konsultan Word Bank (Pedoman umum, 2008: 62 dalam Virgoreta dkk, 2015: 3). Hal ini sesuai dengaan penjelasan yang terdapat dalam Perpres no 15 tahun 2010 pasal 5 ayat 1 poin a, yaitu "Kelompok program bantuan sosial terpadu berbasis keluarga, bertujuan untuk melakukan pemenuhan hak dasar, pengurangan beban hidup, dan perbaikan kualitas hidup masyarakat miskin".

PKH merupakan salah satu program yang tepat dalam mengentaskan kemiskinan, karenamemberikan sumbangsih terhadap kemajuan atau perkembangan pendidikan. Program PKH juga memberikan kontribusi terhadap pendidikan. Sebagaimana hasil kajian yang termuat dalam sebuah jurnal memperoleh hasil yaitu "dana bantuan PKH yang diberikan untuk meningkatkan partisipasi pendidikan di Kecamatan Muara Tiga Kabupaten Pidie adalah telah dilakukan dengan sangat efektif, dimana rata-rata tingkat efektifitas pemberian bantuan PKH dari tahun 2008-2013 mencapai 95,58 persen. Bantuan PKH mampu menjelaskan atau mempengaruhi partisipasi pendidikan anak-anak RTSM di Kecamatan Muara Tiga Kabupaten Pidie mencapai 96,8 persen dan sisanya sebesar 3,2 persen di pengaruhi oleh variabel lainnya diluar model kajian ini. Pemberian bantuan PKH hendaknya tepat sasaran dan benar-benar ditujukan untuk meningkatkan pendidikan anak. Hal ini penting, karena bantuan tersebut hanya bersifat sementara dan lebih terfokus untuk memutuskan mata rantai kemiskinan" (Lidiana dkk, 2014:1).

Keadilan sosial bukanlah faktor yang dimaksudkan atas dasar pertimbangan moral, yaitu demi keadilan saja, tetapi faktor ini berkaitan dengan kelestarian pembangunan. Bila terjadi kesenjangan yang terlalu mencolok antara orangorang kaya dan miskin, masyarakat yang bersangkutan menjadi rawan secara politis (Arif Budiman, 200: 8).

PKH adalah program pemberian bantuan sosial bersyaratkepada keluarga miskin (KM) yang ditetapkan sebagai keluarga penerima manfaat
PKH.Dalam istilah internasional dikenal dengan Conditional Cash Transfers (CCT), di banyak negara berkembang, program perlindungan sosial adalah bagian penting dalam strategi pembangunan. Perlindungan sosial bertujuan mengurangi risiko sosial, meningkatkan kesetaraan, mengurangi kemiskinan karena potensi manfaat jangka panjang perubahan perilaku positif akibat kondisionalitas dalam CCT.(A Philosophical Framework for Conditional Cash Transfers, Jaron Abelsohn, 2011).

Menurut Suharto (2007: 55) "bantuan sosial merupakan salah satu bentuk program jaminan sosial (social security) yang berupa tunjangan uang, barang, atau pelayanan kesejahteraan yang umumnya diberikan kepada populasi paling rentan yang tidak memiliki penghasilan yang layak bagi kemanusiaan".

Menurut Tim Direktorat Jaminan Sosial (2013: 13) sejak tahun 2007 Pemerintah Indonesia telah melaksanakan Program Bantuan Tunai Bersyarat (BTB) yang saat ini dikenal dengan nama Program Keluarga Harapan (PKH) guna terlaksananya percepatan penanggulangan kemiskinan sekaligus pengembangan kebijakan dibidang perlindungan sosial. Program Bantuan Tunai Bersyarat atau disebut Conditional Cash Transfers(CCT), telah dilaksanakan di beberapa negara dan cukup berhasil dalam menanggulangi kemiskinan yang dihadapi negara-negara yang melaksanakan CCT. PKH lebih dimaksudkan sebagai upaya membangun sistem perlindungan sosial kepada masyarakat miskin dalam rangka mempertahankan dan meningkatkan kesejahteraan sosial penduduk miskin sekaligus sebagai upaya memotong rantai kemiskinan yang terjadi pada masyarakat Indonesia selama ini.

Tujuan dibuatnya program keluarga harapan oleh pemerintah yaitu untuk memutus tali kemiskinan pada Rumah Tangga Sangat Miskin (RTSM). Pada hakikatnya Program Keluarga Harapan Juga memiliki tujuan umum dan tujuan khusus. Tujuan Program Keluarga Harapan secara umum adalah untuk meningkatkan kualitas sumber daya manusia, serta merubah perilaku peserta Program Keluarga Harapan yang relatif kurang mendukung peningkatan kesejahteraan masyarakat. Adapun yang menjadi tujuan khusus dari Program Keluarga Harapan adalah untuk meningkatkan kualitas kesehatan RTSM/KSM, meningkatkan taraf pendidikan anak-anak RTSM/ KSM, meningkatkan akses dan kualitas pelayanan 
pendidikan dan kesehatan, khususnya bagi anakanak RTSM/KSM (Tim Direktorat Jaminan Sosial, 2015: 2) .

Menurut Direktorat Jaminan Sosial (Tim Direktorat Jaminan Sosial, 2013: 10) adapun landasan hukum pelaksanaan program keluarga harapan berpedoman pada perundang-undangan yang berlaku sebagai berikut:

1. Undang-undang nomor 40 Tahun 2004 tentang, Sistem Jaminan Sosial Nasional.

2. Undang-undang nomor 13 Tahun 2011 tentang, Penanganan Fakir Miskin.

3. Inpres nomor 1 Tahun 2013 tentang, Pencegahan dan Pemberantasan Korupsi poin lampiran ke 46 tentang Pelaksanaan Transparansi Penyaluran Bantuan Langsung Tunai Bersyarat Bagi Rumah Tangga Sangat Miskin (PESERTA PKH) Sebagai Peserta Program Keluarga Harapan (PKH).

4. Inpres nomor 3 Tahun 2010 tentang, Program Pembangunan yang Berkeadilan poin lampiran ke 1 tentang Penyempurnaan Pelaksanaan Program Keluarga Harapan.

5. Peraturan Presiden nomor 15 Tahun 2010, tentang Percepatan Penanggulangan Kemiskinan.

6. Peraturan Menteri Keuangan nomor 81/ PMK.05/2012, tentang Belanja Bantuan Sosial pada Kementerian Negara / Lembaga.

7. Surat Keputusan Direktur Jenderal Perlindungan dan Jaminan Sosial nomor 121/ LJS/06/2013, tentang Penetapan Perubahan Bantuan Tetap dan Bantuan Komponen PKH.

Mulai tahun 2012 basis bantuan Program Keluarga Harapan diarahkan pada KSM (orang tua-ayah, ibu dan anak). Perubahan ini untuk mengakomodasi prinsip bahwa keluarga adalah satu unit yang sangat relevan dengan peningkatan kualitas sumber daya manusia. Orangtua mempunyai tanggung jawab terhadap pendidikan, kesehatan, kesejahteraan, dan masa depan anak. Keluarga adalah unit yang relevan dalam upaya memutus rantai kemiskinan antar generasi. Menurut Tim Direktorat Jaminan Sosial, (2013: 23) Peserta PKH adalah RTSM/KSM yang sesuai dengan kriteria BPS dan memenuhi satu atau beberapa kriteria program, yaitu:

1. Ibu hamil/ibu nifas/anak balita,

2. Anak usia 5-7 tahun yang belum masuk pendidikan dasar (anak pra sekolah),

3. Anak SD/MI (usia 7-12 tahun),

4. Anak SLTP/ MTs (usia 12-15 tahun),
5. Anak usia 15-18 tahun yang belum menyelesaikan pendidikan dasar.

Setiap penerima PKH diberikan kartu peserta sebagai bukti kepesertaan. Nama yang tercantum dalam kartu peserta Program Keluarga Harapan RTSM adalah nama perempuan dewasa (ibu, nenek, bibi dan anak perempuan dewasa) yang mengurus RTSM. Sedangkan nama yang tercantum dalam kartu peserta Program Keluarga Harapan KSM adalah perempuan dewasa (ibu dan anak perempuan dewasa). Dalam hal kondisi tertentu dapat digantikan oleh kepala keluarga. Kartu tersebut digunakan untuk menerima bantuan PKH dan bantuan sosial lainnya. Menurut Tim Direktorat Jaminan Sosial $(2015: 28)$ peserta PKH diikutsertakan pada program komplementaritas, meliputi Program Indonesia Pintar (PIP), Program Indonesia Sehat (PIS), Program Simpanan Keluarga Sejahtera (PSKS), dan bantuan beras miskin (RASKIN) serta program penanggulangan kemiskinan, meliputi Kelompok Usaha Bersama (KUBE), Usaha Ekonomi Produktif (UEP), Rumah tinggal layak huni.

Proses belajar mengajar yang efektif yaitu adanya interaksi timbal balik yang baik antara pendidik dan peserta didik. Pendidik yang bertugas untuk mendidik dan membimbing tentunya harus didukung dengan semangat atau motivasi belajar siswa yang baik sehingga tujuan proses belajarmengajarnya dapat tercapai.

Motivasi merupakan suatu faktor terpenting dalam mewujudkan keberhasilan capaian pembelajaran. Menurut Mc. Donald dalam Sardiman (2014: 73) "motivasi adalah perubahan energi dalam diri seseorang yang ditandai dengan munculnya feeling dan didahului dengan tanggapan terhadap adanya tujuan". Menurut Dimyati (2013: 80) "menyatakan motivasi dipandang sebagai dorongan mental yang menggerakkan dan mengarahkan perilaku manusia, termasuk perilaku belajar".

Ada tiga komponen utama dalam motivasi yaitu: kebutuhan, dorongan, dan tujuan (Dimyati, 2013: 81) . Kebutuhan terjadi apabila individu merasa ada ketidakseimbangan antara apa yang ia miliki dan yang ia harapkan. Dorongan merupakan kekuatan mental untuk melakukan kegiatan dalam rangka memenuhi harapan. Dorongan juga merupakan kekuatan mental yang berorientasi pada pemenuhan harapan atau pencapaian tujuan. Tujuan adalah hal yang ingin dicapai oleh seorang individu. Tujuan tersebut 
mengarahkan perilaku dalam hal ini perilaku belajar.

Berdasarkan pendapat diatas dapat ditarik kesimpulan bahwa motivasi belajar merupakan faktor pendukung dari luar diri seseorang yang bisa mendorong seseorang untuk melakukan halhal yang ingin dicapai. Motivasi biasanya dilakukan oleh orang lain, misalnya guru, keluarga dan juga dari masyarakat dilingkungan kehidupan individu tersebut. Motivasi belajar ada yang berasal dari dalam diri individu misalnya keinginan untuk mendapat keterampilan tertentu, memperoleh informasi dan pengertian, mengembangkan sikap untuk berhasil, menyenangi kehidupan, menyadari sumbangannya terhadap usaha kelompok, dan keinginan diterima oleh orang lain.

\section{METODE}

Metode merupakan suatu strategi dalam membantu pengkajian untuk mendapatkan suatu capaian yang diharapkan. Menurut Sugiyono (2015: 2) "metode kajian pada dasarnya merupakan cara ilmiah untuk mendapatkan data dengan tujuan dan kegunaan tertentu". Metode deskriptif kualitatif sebagaimana dikemukakan oleh Nawawi (2012: 67) "metode deskriptif dapat diartikan sebagai prosedur pemecahan masalah yang diselidiki dengan menggambarkan/ melukiskan keadaan subyek/obyek kajian pada saat sekarang berdasarkan fakta-fakta yang tampak, atau sebagaimana adanya".

Subjek dalam kajian ini adalah Keluarga Penerima Manfaat Program Keluarga Harapan di Kabupaten Sintang Kalimantan Barat. Objek pada kajian ini adalah Anak-anak Keluarga Penerima Manfaat Program Keluarga Harapan di Kabupaten Sintang Kalimantan Barat.

Penentuan subjek dan objek kajianpurposive sampling atau sampel bertujuan. Jumlah sampel disesuaikan dengan kebutuhan kajian. Subjek dipilih menggunakan teknik Snowbal Sampling atau sampel jenuh, dimana jumlah subjek kajian cenderung bertambah berdasarkan keperluan. Kriteria penentuan subjek kajian diantaranya: Keluarga Penerima Manfaat Program Keluarga Harapan di Kabupaten Sintang Kalimantan Barat.

Data atau informasi yang paling penting untuk dikumpulkan dalam kajian ini sebagian besar berupa data kualitatif. Sumber data yang dimanfaatkan dalam kajian ini adalah: (1) Informan, adalah orang yang dipandang mengetahui permasalahan yang akan diteliti dan bersedia untuk memberikan informasi kepada peneliti berupa kata-kata. Informan dalam kajian ini adalah orangtua penerima manfaat Program Keluarga Harapan; dinas sosial dan Anak penerima manfaat Program Keluarga Harapan. (2) Peristiwa dan Lokasi; Kajian kualitatif yaitu kajian yang tidak lepas dari wawancara dan obervasi lapangan yang melibatkan tempat, pelaku dan peristiwa yang terjadi. Dengan adanya peristiwa peneliti dapat mengetahui secara lansung persoalan yang terjadi. (3) Dokumen; Merupakan data pendukung berupa arsip-arsip dan foto yang berkaitan dengan kebutuhan kajian.

Instrumen kajian ini terdiri dari panduan wawancara, panduan observasi dan dokumentasi.Adapun instrumen rencanayang akan digunakan pada kajian ini terdiri dari: (a). Lembar Observasi. Dalam observasi ini pengkaji hanya sebagai pengamat yang hadir di lokasi. Observasi langsung ini akan dilakukan dengan cara formal dan informal, untukmengamati kegiatan implementasi hak warga negara melalui program PKH. (b). Pedoman Wawancara. Wawancara digunakan untuk memperoleh data bagaimana Implementasi Hak Warga Negara Melalui Penanggulangan Kemiskinan Berperspektif Gender Program Keluarga Harapan Terhadap Motivasi Belajar Anak Keluarga Penerima Manfaat di Kabupaten Sintang. Wawancara dilakukan dengan 2 ( dua) tahapan yaitu Wawancara terstruktur dan wawancana mendalam (dept interview). (c). Catatan lapangan, digunakan untuk mencatat hal-hal yang terjadi dan menggambarkan keadaan dalam kajian untuk menunjang pembahasan dankesimpulan.(d). Dokumentasi, merupakan data tambahan, bukan hanya berupa foto-foto saja melainkan juga dapat berupa arsip-arsip yang mendukung data kajian.

Ada 3 tahapan dalam kajian ini yaitu:

1. Tahap Perencanaan

1) Mengurus perijinan dan administrasi terkait dengan rencana pelaksanaan kajian.

2) Peneliti menyusun skenario pelaksanaan kajian terhadap keluarga penerima manfaat di kabupaten Sintang.

3) Menyusun instrumen kajian yang berupa panduan wawancara,panduan observasi dan studi dokumentasi yang diperlukan dalam kajian.

4) Melakukan analisis kualitas instrumen dengan validator internal atau para ahli yang relevan. 
2. Tahap Pelaksanaan

Tahap ini merupakan tahap pengumpulan data. Adapun beberapa kegiatan yang dilakukan pada tahap ini antara lain:

1) Tahap eksplorasi atau observasi umum.

2) Tahap eksplorasi terfokus.

3) Tahap pengumpulan data.

4) Tahap konfirmasi data.

3. Tahap analisis data

Setelah selesai proses pengumpulan data, diperoleh sejumlah data kualitatif. Analisis dan pengolahan data berpedoman pada data yang terkumpul dan pertanyaan kajian. Teknik analisis data yang digunakan adalah teknik analisis data deskriptif kualitatif memanfaatkan persentase hanya merupakan langkah awal dari proses analisis data (Arikunto, 2000: 352). Dalam proses selanjutnya analisis data kualitatif terdiri dari empat alur kegiatan yang terjadi secara bersamaan, yaitu catatan lapangan, pengumpulan informasi, penyajian informasi, dan penarikan kesimpulan (Miles dan Huberman, 1992: 16-21). Proses analisis data dilakukan secara simultan yang mencakup klarifikasi, interpretasi dan analisis data.

\section{HASIL DAN PEMBAHASAN}

Implementasi Hak Warganegara Melalui Penanggulangan Kemiskinan Berperspektif Gender Program Keluarga Harapan (PKH) Terhadap Motivasi Belajar Anak Keluarga Penerima Manfaat (KPM) Di Kabupaten Sintang Berdasarkan hasil wawancara yang dilakukan terhadap dinas sosial yaitu 1 orang koordinator kabupaten, 1 orang operator kabupaten dan 3 orang pendamping, serta 3 siswa SD, 3 siswa SMP, 3 siswa SMA dan 1 orang mahasiswa PT beserta orang tuannya. Hasil kajian terungkap beberapa temuan sebagai berikut:

\section{Implementasi Hak Warga Negara Melalui Penanggulangan Kemiskinan Berspektif Gender Program Keluarga Harapan Di Kabupaten Sintang}

Berdasarkan hasil wawancara terhadap koordinator, operator dan pendamping. Program bantuan sosial PKH di Kabupaten Sintang mulai ada sejak tahun 2013. Penerima PKH adalah warga miskin yang telah mendapatkan penetapan dari pemerintah yang memenuhi beberapa kriteria yakni tergolong tidak mampu (miskin) dan memiliki anak sedang sekolah baik di SD, SMP dan SMA yang terdapat di Kabupaten Sintang. Adapun syarat bagi penerima bantuan PKH merupakan Ibu rumah tangga yang memiliki anak di bangku sekolahan. Untuk menerima bantuan PKH prosedur yang harus dilalui bahwa ibu rumah tangga tersebut telah terdata sebagai warga miskin sesuai aturan standar kemiskinan yang telah ditetapkan oleh kementerian Sosial, setelah itu adanya validasi yang dilakukan oleh pendamping PKH kepada yang bersangkutan. Masyarakat penerima bantuan PKH di Kabupaten Sintang dalam periode tiga tahun terakhir berjumlah 18.000 orang. Pemberian bantuan ini merupakan implementasi dari pemberian hak warga negara yang kurang mampu (miskin) untuk dapat meningkatkan taraf hidupnya menuju masyarakat sejahtera.

Dana bantuan PKH yang diberikan kepada warga yang tidak mampu terkhusus bagi anaknya sedang sekolah berjumlah RP. 500.000,- per triwulan. Adapun bantuan ini hanya diberikan kepada satu keluarga satu saja meskipun jumlah anaknya lebih dari satu yang sedang sekolah. Dalam penyaluran bantuan ini berupa dana tunai yang ditransfer melalui Bank Mandiri (untuk Kabupaten Sintang), sehingga setiap warga yang memperoleh dana tersebut harus mengambil sendiri ke Bank yang dimaksud dan tidak boleh diwakilkan. Namun apabila yang bersangkutan benar adanya tidak bisa mengambil uangnya dengan alasan yang dapat dipertanggungjawabkan maka harus dibuatkan surat kuasa kepada pihak yang akan mengambil.

Selama ini operator kabupaten belum menemukan kasus atau permasalahan penyalahgunaan untuk peruntukan kegunaan uang sesuai dengan yang terdapat diperaturan. Hal ini karena ada pendampingan secara intensif kepada warga yang menerima. Pendampingan ini dalam bentuk program triwulan atau tiga bulan sekali. Program ini berupa memberikan motivasi kepada ibu rumah tangga yang mendapat bantuan PKH bahwa dana yang didapat untuk membayar biaya sekolah anaknya. Untuk membuktikan kebenarannya maka tim pendamping PKH turun ke sekolah untuk memberikan form pengisian data yang diberikan kepada pihak sekolah untuk mengisinya sesuai dengan data riil bahwa anak yang sedang sekolah benar adanya telah dibayar biaya sekolahnya.

Penerima bantuan yang diberhentikan ada berbagai alas an, yaitu apabila anak yang sedang 
sekolah SMA kelas tiga dan sudah lulus serta tidak ada lagi anak yang sekolah maka secara otomatis bisa digugurkan.

Berdasarkan hasil wawancara terhadap orang tua KPM terungkap bahwa mereka merasakan manfaat dan sangat terbantu dengan hadirnya program pemerintah ini. Sebagai warga negara yang tergolong kurang mampu, bantuan semacam ini dengan pembinaan yang baik dianggap sebagai bagian dari perhatian pemerintah dalam memberikan akses dan kemajuan pendidikan. Orang tua telah mengalokasikan bantuan yang diterima untuk membayar atau membeli kebutuhan sekolah anakanak mereka. Orang tua juga selalu memotivasi anak yang sekolah agar dapat memperoleh prestasi dan menempuh pendidikan setinggi-tingginya. Orang tua beranggapan bahwa melalui pendidikan dan prestasi yang diperoleh anak-anak mereka dapat membantu mereka memperbaiki taraf hidup atau menjadi masyarakt sejahtera.

Bagi anak KPM yang sedang menempuh pendidikan, berdasarkan hasil wawancara terungkap bahwa anak-anak sangat termotivasi untuk sekolah. Hal ini didasarkan pada beberapa alasan, diantaranya mereka merasa terbantu terutama dari segi biaya, banyak sekali kemudahan yang mereka peroleh, misalnya selain dari dana yang diberikan orang tua; mereka juga dengan mudah meperoleh bantuan beasiswa kurang mampu dan kemudahan-kemudahan lainnya. Selain itu, anakanak juga memiliki kesadaran bahwa mereka telah diberikan hak oleh negara untuk mengases pendidikan sama dengan warga negara lainnya. Motivasi belajar anak-anak KPM pada dasarnya bervariasi, dapat dibagi menjadi dua yakni secara internal maupun eksternal. Internal berupa kesadaran pribadi anak-anak untuk masa depan, ingin mengapai cita-cita, ingin bekerja, ingin memperbaiki taraf hidup, ingin keluar dari garis kemiskinan dan lain-lain. Sedangkan secara eksternal, anak-anak KPM termotivasi belajar karena dorongan orang tua, pendamping $\mathrm{PKH}$, guru dan lingkungan. Mereka merasa bahwa peran serta orang lain tersebut mendorong mereka untuk maju.

\section{Motivasi Belajar Anak Keluarga Penerima Manfaat Di Kabupaten Sintang.}

Dari sejumlah 18. 402 anak KPM yang sekolah baik ditingkat SD, SMP, SMA, berdasarkan hasil temuan kajian melalui wawancara, observasi maupun studi dokumentasi kepada orang tua, siswa, petugas PKH dan kepala sekolah, bahwa anak-anak mengalami peningkatan motivasi belajar. Ini terbukti dari banyaknya anak yang berprestasi baik ditingkat lokal maupun nasional dan internasional. Hal tersebut tidak terlepas dari peran orang tua dan pendamping $\mathrm{PKH}$ yang selalu memberikan motivasi dan pemahaman akan pentingnya pendidikan. Motivasi anak-anak untuk sekolah terdiri dari dua, yakni secara internal dari kesadaran diri sendiri si anak dan faktor internal yakni dari motivasi orang tua dan lingkungan.

Sejauh ini belum ada anak keluarga penerima manfaat yang berhenti sekolah setelah menerima bantuan dari PKH. Hal ini telah dijelaskan dengan adanya pendampingan dari tim $\mathrm{PKH}$ untuk momotivasi terutama orang tuanya apabila anak berhenti sekolah maka tidak akan mendapatkan bantuan lagi. Selain itu pendamping $\mathrm{PKH}$ memberikan motivasi berupa penyampaian tujuan jangka panjang dari PKH untuk keberlangsungan pencerdasan generasi penerus. Terdapat aturan yang mengatur bahwa anak harus tetap rajin sekolah baik di SD, SMP, dan SMA dimana absennya atau kehadirannya minimal $85 \%$. Apa bila kurang dari $85 \%$ tiga kali berturut-turut maka bantuannya akan dihentikan sementara, dan apabila tidak diindahkan sampai kepada pemutusan untuk dapat bantuan lagi. Untuk mengetahui data $85 \%$ kehadiran tim pendampingan $\mathrm{PKH}$ memberikan form pengisian kepada pihak sekolah dalam waktu triwulan sekali. Dengan demikian dengan adanya pendampingan secara intensif sejauh ini belum ada anak penerima bantuan sampai berhenti sekolah.

Terdapat banyak anak yang berprestasi baik dibidang akademik maupun non akademik. Terdata 59 anak yang berprestasi baik ditingkat lokal, nasional maupun internasional. Satu orang anak KPM yang berprestasi ditingkat internasional atas nama Fitri Rini Ariesti anak KPM ibu atas nama Wihelmina Runan dengan prestasi diterima di University Science and Technology Of China (USTC), jurusan Public Administration melalui jalur beasiswa Chinese Goverment Scholarship (CGS). Delapan orang anak KPM berprestasi ditingkat nasional, yang terdiri dari prestasi dibidang pendidikan dan seni, dan 50 orang yang berprestasi ditingkat lokal, seperti juara kelas, juara perlombaan pada tingkal lokal sekolah, tingkat kecamatan, kabupaten dan provinsi. Ini menunjukkan bahwa anak-anak KPM PKH 
memiliki motivasi dan prestasi yang baik dalam belajar.

Sebagaimana yang diungkapkan oleh pendamping dan operator PKH Kabupaten Sintang, bahwa hal ini tidak lepas dari pembinaan dan motivasi yang diberikan oleh petugas. Peningkatan keberhasilan anak ini dapat terwujud karena memiliki program pendampingan kepada orang tuanya untuk momotivasi anaknya dalam sekolah. Selain itu adanya aturan minimal kehadiran $85 \%$ hal ini menjadikan anak rajin masuk sekolah dan hasilnya mendapatkan peningkatan. Selain itu anak merasa telah mendapat bantuan sehingga memperoleh kesempatan untuk sekolah sehingga anak bersemangat bersekolah.

c. Implementasi Hak Warga Negara Melalui Penanggulangan Kemiskinan Berspektif Gender Program Keluarga Harapan Terhadap Motivasi Belajar Anak Keluarga Penerima Manfaat Di Kabupaten Sintang

Hasil wawancara terhadap responden implementasi hak warga negara melalui penanggulangan kemiskinan berspektif gender program keluarga harapan terhadap motivasi belajar anak keluarga penerima manfaat di Kabupaten Sintang, dilakukan melalui penyaluran bantuan yang dilaksanakan oleh petugas (pendamping) PKH sesuai dengan jadwal dan prosedur yang telah ditentukan. Dalam penyaluran bantuan, untuk menjamin kelancaran dan akuntabilitas petugas maka dilakukan dengan melibatkan kerjasama berbagai pihak, seperti petugas keamanan, perbankan dan pendamping. Kegiatan penyaluran bantuan juga sering mendapat pengawasan atau monitoring dari dinas sosial khususnya melalui kepala bidang sosial PKH.

Proses pemberian bantuan yaitu awalnya PKH mendapatkan data sekabupaten Sintang, setelah itu data tersebut diserahkan kepada pendamping setiap kecamatan untuk dilakukan proses verifikasi data untuk memastikan kebenarannya. Setelah data valid selanjutnya setiap pendamping kecamatan memberikan arahan atau tatacara memperoleh dana bantuan. Adapun tatacaranya setiap warga yang dapat bantuan untuk datang langsung ke Bank Mandiri untuk menyerahkan persyaratannya, setelah lengkap maka warga dapat mengambil dana tunai secara langsung melalui Bank Mandiri. Proses ini dilakukan untuk menjamin keberlangsungan kegiatan PKH agar setiap warga negara yang berhak menerima mendapatkan jaminan kepastian haknya sebagai warga negara.

Dilapangan memang masih terdapat bayak kendala yang dihadapi, hal ini berdasarkan masukan dari warga setempat maupun dari pihak desa bahwa ada warga yang seharusnya dapat bantuan namun tidak dapat. Hal ini dikarenakan semua data itu sudah baku dari pemerintah sedangkan PKH sebagai pelaksana saja. Selain itu jarak tempuh yang jauh dan medan jalannya yang berlumpur menghambat untuk tim pendamping cepat sampai pada tujuan.

Terungkap juga harapan responden, baik petugas maupun KPM bahwa PKH harus tetap berlanjut kedepannya, karena program ini sangat membantu untuk mengentaskan kemiskinan. Bedasarkan pertimbangan bahwa selama ini PKH tersebut sangat efisien selain membantu pendidikan PKH juga memberikan bantuan untuk kesehatan dan lansia. Ketiga program unggulan ini sangat mendukung dengan program pemerintah dalam mengentaskan kemiskinan sebagai hak warga negara.

Kedepan harapan responden adalah bahwa adanya jalinan kerja sama antara kaum pendidik dan dunia akademisi yang terintegrasi secara berkelanjutan, karena PKH perlu adanya suatu evaluasi dari pihak akademisi demi terwujudnya tujuan PKH seutuhnya. Menurut operator dan pendamping program, $\mathrm{PKH}$ telah mampu menurunkan angka kemiskinan sesuai yang diprogramkan pemerintah, hal ini berdasarkan perkembangan data yang diperoleh disetiap kecamatan sekabupaten Sintang. Dengan adanya bantuan dari PKH keluarga mereka terbantu dan mengalami perubahan menjadi lebih baik.

Berdasarkan hasil observasi selama dilapangan, ditemukan bahwa implementasi hak warga negara melalui penanggulangan kemiskinan berperspektif gender Program Keluarga Harapan di Kabupaten Sintang berjalan sesuai dengan harapan, berdasarkan dilapangan benar-benar terlaksana dengan baik sesuai dengan yang diprogramkan Dinas Sosial melalui Program PKH. Selanjutnya motivasi belajar anak Keluarga Penerima Manfaat di Kabupaten Sintang ditemukan bahwa mereka memiliki semangat yang tinggi untuk bersekolah, hal ini ditandai dengan adanya prestasi yang mereka peroleh. Adapun prestasi mereka terdiri dari bidang akademik dan non akademik dari tingkat lokal, nasional dan internasional. 
Terakhir yaitu implementasi hak warga negara melalui penanggulangan kemiskinan berperspektif gender Program Keluarga Harapan terhadap motivasi belajar anak Keluarga Penerima Manfaat di Kabupaten Sintang telah terlaksana dengan baik. Bantuan yang harus disalurkan kepada penerima sudah sampai kepada setiap orang yang berhak. Ini terbukti dengan adanya siswa yang mengeyam pendidikan disekolah baik tingkat SD, SMP, SMA maupun Kuliah. Bahkan mereka sangat termotivasi untuk mengenyam pendidikan dan berprestasi setelah mendapatkan bantuan biaya pendidikan yang diberikan oleh PKH Kabupaten Sintang. Secara khusus rincian hasil observasi selama dilapangan akan dideskripsikan dibawah ini.

Penerima bantuan PKH adalah mereka yang telah terdata layak menerima. Kelayakan ini berdasarkan data dan hasil verifikasi petugas (pendamping) yang dilakukan secara berkala. Saat pembagian bantuan, KPM yang mengambil harus dapat menunjukan kartu PKH yang sah dan apabila berhalangan dapat diwakilkan dengan syarat membuat surat kuasa yang ditandatangi diatas matrai. Berdasarkan hasil observasi, pada 3 kecamatan yang dilaksanakan pada bulan Juni 2018, tampak proses pelaksanaan pembagian bantuan berjalan lancar dan sesuai prosedur yang telah ditetapkan dengan melibatkan kerjasama antara petugas $\mathrm{PKH}$, perbankan dan aparat keamanan setempat. Terdapat juga pengawasan internal yang dilakukan oleh koordinator dan dinas sosial. Tidak ada kendala yang berarti dalam pelaksanaan kegiatan ini dilapangan.

Hasil observasi terhadap anak KPM yang bersekolah baik di SD, SMP, SMA maupun yang kuliah, merekasemua memiliki semangat belajar dan kesadaran yang tinggi menempuh pendidikan. Mereka rata-rata dapat berprestasi di sekolah. Pada tahun 2018, terdapat beberapa diantara mereka yang berprestasi bahkan ada yang sampai ditingkat internasional yaitu berhasil lulus beasiswa kuliah Strata 2 ke negara China. Ada juga beberapa yang memperoleh prestasi lokal, misalnya juara kelas, juara dibidang olahraga, paskibra dan lainlain.

Penggunaan atau pemanfaatan bantuan yang diterima KPM khususnya yang berkaitan dengan pendidikan sudah dimanfaatkan dengan baik, bahkan dari hasil observasi banyak orang tua yang memberikan semua bantuan yang diterima untuk sekolah anaknya. Hal ini terjadi karena bantuan yang dialokasikan sangat terbatas kisaran Rp. 500.000; sedangkan jumlah anak-anak yang sekolah rata-rata lebih dari satu orang, ini tentu menyebabkan kekurangan. Ada beberapa warga dampingan yang telah berhasil menyisihkan bantuan yang diberikan untuk modal usaha. Bahkan ada salah satu kelompok yang telah berhasil membangun usaha berkebun cabe bersama lewat kelompok yang diberi nama Sukacita Desa Buluk Panjang, kelompok ini telah berhasil mewakili provinsi Kalimantan Barat dalam ajang penghargaan di Appreciation Day PKH seIndonesia tahun 2017 di Surabaya dengan judul Setitik Harapan Dari Perempuan-Perempuan Tangguh. Bentuk usaha yang dilakukan adalah berkebun cabe rawit, dari mengolah lahan, menanam, merawat, memanen dan menjual dilakukan oleh ibu-ibu KPM. Berawal dari modal usaha Rp. 100. 000; dari setiap anggota telah mendapat keuntungan atau hasil usaha yang dapat digunakan untuk membantu perekonomian keluarga.

\section{SIMPULAN}

Berdasarkan hasil dan pembahasan kajian yang telah diperoleh, dapat kesimpulan sebagai berikut:

1. Implementasi Hak Warga Negara Melalui Penanggulangan Kemiskinan Berspektif Gender Program Keluarga Harapan Di Kabupaten Sintang sudah terlaksana dengan baik, hal tersebut diindikasikan dari beberapa temuan diantaranya telah diterima bantuan uang tunai kepada warga yang berhak menerima dengan bantuan uang tunai sebesar Rp. 1.590.000,- per keluarga yang diberikan secara per triwun. Selanjutnya bantuan ini langsung dirasakan oleh anak penerima manfaat program PKH untuk bersekolah, mereka sangat senang mendapatkan bantuan hal ini terbukti mereka telah mendapatkan prestasi baik dibidang akademik maupun non akademik.

2. Motivasi Belajar Anak Keluarga Penerima Manfaat Di Kabupaten Sintang sangat baik, hal tersebut dapat dilihat dari banyaknya anakanak KPM yang berprestasi baik dibidang akademik maupun non akademik. Terdapat 59 anak yang berprestasi baik ditingkat lokal, naisonal maupun internasional.

3. Implementasi Hak Warga Negara Melalui Penanggulangan Kemiskinan Berspektif Gen- 
der Program Keluarga Harapan Terhadap Motivasi Belajar Anak Keluarga Penerima Manfaat Di Kabupaten Sintang sangat relevan, karena telah mampu memfasilitasi anak yang kurang mampu untuk memperoleh akses pendidikan sebagai hak warga negara yang sama dengan anak yang lainnya, seperti akses

\section{DAFTAR RUJUKAN}

Arikunto Suharsimi. 2009. Prosedur Kajian Suatu Pendekatan Praktik, Jakarta: Rineka Cipta.

Budiman, Arif. (2000). Teori Pembangunan Dunia Ketiga. Jakarta: Pt. Gramedia Pustaka Utama.

Dimyati, Mudjiono. (2013). Belajar dan Pembelajaran. Jakarta: Rineka Cipta

Direktorat Jaminan Sosial. 2013. Pedoman Operasional Penyaluran Dana Bantuan $P K H$. Jakarta: Direktorat Jenderal Perlindungan dan Jaminan SosialKementerian Sosial RI.

Direktorat Jaminan Sosial. 2013. Buku Pedoman Umum PKH. Jakarta: Direktorat Jenderal Perlindungan dan Jaminan SosialKementerian Sosial RI.

Direktorat Jaminan Sosial. 2015. Buku Kerja Pendamping PKH . Jakarta. Direktorat Jenderal Perlindungan dan Jaminan Sosial Kementerian Sosial RI

Lidiana dkk. 2014. Pengaruh Dan Efektifitas Bantuan Program Keluarga Harapan (Pkh) Terhadap Partisipasi Pendidikan Di Kecamatan Muara Tiga Kabupaten Pidie. Jurnal Ilmu Ekonomi Volume 2, No. 2, Mei 2014 halaman 31-38.

Miles, Mattew B dan Hubermen, Michael. 1992. Analisa Data Kualitatif: Buku Sumber Tentang Metode Baru, Terjemahan Tjetjep Rohendy (2007), Jakarta: UI Press. memperoleh kemudahan dalam memperoleh beasiswa dan keringanan biaya pendidikan dengan bantuan yang diterima secara tunai. Namun disisi lain masih dianggap belum dapat maksimal untuk membiayai sekolah karena secara tunai bantuan yang diterima secara langsung hanya Rp. 500.000; per triwulan.

Nawawi, Hadari. (2012). Metode Kajian Bidang Sosial. Yogyakarta: Gadjah Mada University Press.

Purwanto, S.A., dkk. 2013. Implementasi Kebijakan Program Keluarga Harapan (Pkh) Dalam Memutus Rantai Kemiskinan (Kajian Di Kecamatan Mojosari Kabupaten Mojokerto). Jurnal Wacana Vol. 16, No. 2 tahun 2013 Hal. 79-96.

Sardiman. (2014). Interaksi dan Motivasi Belajar Mengajar. Jakarta: Rajagrafindo Persada.

Suharto, Edi. (2007). Kebijakan Sosial Sebagai Kebijakan Publik. Bandung: Alfabeta.

Sugiyono. (2015). Metode Kajian Kuantitatif Kualitatif dan $R \& D$. Bandung: Alfabeta.

Virgoreta, D. A., dkk. 2015. Implementasi Program Keluarga Harapan (Pkh) Dalam Upaya Meningkatkan Kesejahteraan Masyarakat (Studi Pada Desa Beji Kecamatan Jenu, Kabupaten Tuban) Dyah Ayu Virgoreta, Ratih Nur Pratiwi, Suwondo. Jurnal Administrasi Publik (JAP), Vol.2, No12, Hal. 1-6

Winarno. 2009. Pendidikan Kewarganegaraan. Jakarta: Bumi Aksara.

http://setkab.go.id/bps-per-september-2016jumlah-penduduk-miskin-indonesiabekurang-025-juta/. Diakses pada 10 April 2017.

Perpres RI No 15 tahun 2010 Tentang percepatan Penanggulangan Kemiskinan. 